\title{
- Call for Papers - Risk Theory Society Annual Seminar
}

\author{
April 25-27, 2008 \\ Colorado State University \\ Fort Collins, Colorado, USA
}

The Risk Theory Society will hold its annual seminar on April 25-27, 2008 at Colorado State University in Fort Collins, Colorado.

The Risk Theory Society is a group of economists, financial economists, and actuaries who undertake theoretical and applied research in the areas of insurance economics, financial economics related to insurance markets, actuarial science, and, more generally, in the economic analysis of risk and uncertainty. Membership in the Society is earned by presenting a paper at the yearly Risk Theory Society Seminar.

The Risk Theory Society invites interested parties to submit a paper for the 2008 meeting. Authors of selected papers present their research to the members in a seminar setting. Historically, the seminar has been thought provoking and the no-holds-barred approach has allowed for rigorous discussion of an author's findings.

Five-page abstracts or a rough draft of a paper on any relevant topic should be e-mailed by December $17^{\text {th }}, 2007$ to:

\author{
Professor John M. Marshall \\ University of California, Santa Barbara \\ Email: marshall@econ.ucsb.edu
}

The program committee will notify successful authors by January $16^{\text {th }}, 2008$. Papers must be completed and sent to all seminar participants by March $14^{\text {th }}$. Financial support for travel (North American portion only) for one author per paper may be available.

For further information, please contact Professor Marshall or visit the Risk Theory Society web site at http://aria.org/rts. For details regarding local arrangements for the 2008 Seminar, please visit the web site or contact Professor Vickie Bajtelsmit at vickie.bajtelsmit@,business.colostate.edu. 